\title{
Study of the influence of surfactants on the paper properties and degradation
}

\author{
Milda Liubiniené $\dot{e}^{1,2 *}$, \\ Justė Kupčiūnaite் ${ }^{2}$,
}

\author{
Aldona Beganskiené2 \\ ${ }^{1}$ Documentary Heritage Preservation Division, \\ Vilnius University Library, \\ Universiteto St. 3, \\ 01122 Vilnius, Lithuania \\ ${ }^{2}$ Institute of Chemistry, \\ Department of Inorganic Chemistry, \\ Faculty of Chemistry and Geosciences, \\ Vilnius University, \\ Naugarduko St. 24, \\ 03225 Vilnius, Lithuania
}

Surfactants are one of the materials recommended for the cleaning of movable cultural properties. These substances are widespread in other fields - medicine, cosmetics, household appliance industry, etc. Quaternary ammonium compounds are particularly prevalent due to their cleansing and disinfectant properties. Initial studies have shown that surfactants, including quaternary ammonium compounds, have a positive effect on preserved/ restored cultural properties. Using relatively low concentrations of aqueous solutions of these substances, it is possible to obtain sufficiently good results to wash out from the restoration of the document or textiles dirt, acidification of the object and colour changes that cause aging and decomposition processes - hydrolysis and oxidation.

Keywords: paper conservation, washing, surfactants, quaternary ammonium compounds

\section{INTRODUCTION}

While the world is faster and more located in a variety of electronic media, paper, as in all times, remains a popular medium of information gathering, learning and rendering. Paper decomposition - decay chains of cellulose macromolecules - is influenced by hydrolysis and oxidation reactions and acid exposure. Most papers suffer deterioration due to endogenous ( $\mathrm{pH}$, metal ions, lignin, and degradation products) and exogenous (heat, humidity and pollutant gases) contributors. Due to oxidation and acid catalyzed hydrolysis of cellulose the degree of polymerization decreases, e.g. paper becomes brittle because of shorter polymeric chains of cellulose. Acid hydrolysis of cellulose is influenced by sulfur and nitrogen oxides from the atmosphere and paper becomes more acidic. Paper is exposed to light and UV radiation, which causes photochemical degradation of cellulose. This process also has an impact on the paper strength

\footnotetext{
*Corresponding author. Email: milda.liubiniene@mb.vu.lt
}

and its optical properties, such as colour change [1, -3 ]. Moreover, inks containing $\mathrm{Fe}, \mathrm{Cu}$ and other metal ions may influence paper degradation processes [⿰亻⿻ 丨. Another equally important factor in depleting paper is microbiological violations - various types of fungi due to their resulting development of favourable conditions, adequate moisture and temperature. Particularly sensitive to light and humidity is paper that contains lignin. This paper is highly acidic and most vulnerable to microorganisms [5, 6 . It is also important to choose storage materials (boxes, folders, etc.) that are suitable for paper documents and works of art. It is necessary to take into account of what materials they are made, what is their $\mathrm{pH}$, and whether all of this will not affect further degradation of paper.

Restoration procedures are numerous, but the most important one is dry and wet cleaning. This is a critical process because dry cleaning removes paper surface dirt (dust, insect excrements and molds) and, using wet cleaning, soluble acids and soluble coloured compounds are washed out from paper fibers, and that affects $\mathrm{pH}$ and colour. For paper washing 
procedures water and organic solvents with/without surface active materials may be used [ [17].

Surface active agents (surfactants) are materials, which absorb the surface tension of water. They not only improve the wetting ability of water, but also effectively remove dirt and speed up the washing process. Commercial detergents were started to be used by restorers in the 2nd half of the 20th century. Primarily, these substances were used only in leather and textile surface treatment, followed by a gradual attempt to adapt painted surfaces. At that time, Triton $\mathrm{X}-100$ and Synperonic DnB were mainly used. Currently, the most commonly used are non-ionic surfactants [1215. They are widely used because of their good solubility in water and organic solvents, and for their ability to perfectly clean grease and dirt [12 17]. A surfactant is a technologically important substance for many industries. The current industry developments are driven by new specific applications, such as nanotechnologies, and the demand for environment-friendly surfactants (biodegradable, low irritant). During the last decade new surfactants used in the food, medicine and cosmetics industry have been offered.

For the restoration of such sensitive objects it is very important that paper receive least interventions that can damage the document. In order to reduce intervention in paper, scientists and restorers are searching for opportunities to combine several procedures or use the materials which have a double effect. For example, quaternary ammonium compounds contain surfactant and antifungal properties. So after one procedure - washing with a solution - two results are achieved: dirt is washed out from paper and paper is protected from microbiological violators [18-20,21]. Because of antimicrobial properties of quaternary ammonium compounds, they are used in the food and medical industries for surfaces, appliances and tools of cleaning. These materials have a variety of industrial and consumer applications, including use in drilling muds, fabric softeners, hair conditioners, emulsifying agents and sanitizers/disinfectants 22. 23]. It has been determined that the microbiological effect on paper is about $1 \%$ of aqueous solutions of quaternary ammonium compounds. After paper treatment with these solutions, it is recommended that paper be washed well with water (at least 3 times in water at $50^{\circ} \mathrm{C}$ temperature). It was also found that the balance of quaternary ammonium compounds on paper (up to $400 \mathrm{ppm}$ ) did not have a significant effect on paper aging processes [24]. Also, quaternary ammonium compounds are used as chemical corrosion inhibitors, plasticisers for textile and paper production and anti-static agents for cellulose fibers 22,25].

The aim of the work is to investigate the effect of used surface-active substances on the paper properties and degradation process. The commercially available surfactants, Amytis, Tinovetin JUN HC, Tween 20, Bromosept 50 and P3-Triquart, were tested for the possibility to use them in the paper conservation and washing process.

\section{EXPERIMENTAL}

Samples. The used paper (ROTILABO, TYPE $111 \mathrm{~A}$, $99 \%$ made with cotton fibers, paper density $80.0 \mathrm{~g} / \mathrm{m}^{2}$, $\mathrm{PD}=1153, \mathrm{pH}=6.9)$ was selected for experiments. The following commercial surfactants were selected: Amytis (Kremer Pigmente, anionic surfactants, $15-30 \%$ based on protein fatty acid condensate), Tinovetin JUN HC (Kremer Pigmente, non-ionic, $100 \%$ based on ethoxylated aliphatic alcohol), Tween 20 (Sigma-Aldrich, non-ionic, 100\% polysorbate-type based on sorbitan), Triton X-100 (non-ionic, $100 \%$ polyoxyethylene octyl phenyl ether), Bromosept 50 (E-Farma, quaternary ammonium compounds, 50\% didecyldimethylammonium bromide in isopropanol), P3-Triquart (Ecolab, quaternary ammonium compounds, 30\% alkyldimethylbenzylammonium chloride). The quaternary ammonium compounds, Bromosept 50 and P3-Triquart, have not only detergent but also disinfectant properties.

The samples (size $5 \times 15 \mathrm{~cm}$, weight $0.607 \pm 0.005 \mathrm{~g}$ ) were prepared by washing for $30 \mathrm{~min}$ in aqueous surfactant solutions: Amytis (solution concentration 1.0\%), Tinovetin JUN HC (1.0\%), Tween 20 (1.0\%), Triton X-100 (1.0\%), $1.0 \%$ Bromosept $50(0.7$ and $1.0 \%)$ and P3-Triquart (1.0 and $2.0 \%)$. After washing, the prepared samples were rinsed in baths of distilled water for 30 min by changing the water therein every $10 \mathrm{~min}$. In order to accelerate the degradation of cellulose, unwashed, washed with only water and washed samples with surfactants were artificially aged in an oven (SNOL 58/350) set at $85^{\circ} \mathrm{C}$ for $500 \mathrm{~h}$. Infrared (IR) and UV/ Vis spectroscopy, scanning electron microscopy (SEM), degree polymerization (DP) and acidity measurements were used for the sample characterization. The thermogravimetric analysis of the treated samples was also carried.

Acidity measurements of the washed samples were performed according to the standard cold extract ISO (6588-1; 2005) methodology [23]. For the $\mathrm{pH}$ measurement of paper, $0.100 \mathrm{~g}$ samples were weight, cut and placed in a glass bottle, then $5 \mathrm{ml}$ of distilled water was added. The prepared samples were left in the daytime. The extract $\mathrm{pH}$ was measured by a $\mathrm{pH}$ meter (Mettler Toledo MP220). Five measurements were performed on each sample. The error associated to $\mathrm{pH}$ measurements on these samples is \pm 0.2 . The sample $\mathrm{pH}$ was monitored during the aging.

The viscosity-based degree of polymerisation (DP) was determined using the international standard ISO 5351:2004 methodology [26]. The paper was dissolved in the dilute solution of $0.5 \mathrm{~mol} / \mathrm{l}$ copper ethylenediamine (CED). The measurements were performed at $25 \pm 0.1^{\circ} \mathrm{C}$. The output of the viscometric results is the physical parameter describing intrinsic viscosity $[\eta]$. The intrinsic viscosity was calculated using the Martin's formula from the specific viscosity (obtained from the efflux time of a solvent and polymer solution) and the concentration $\mathrm{c}(\mathrm{g} / 100 \mathrm{ml})$ of dry paper. The average viscometric degree of polymerisation DP is given by the equation: 
$[\eta]=K[D P]^{\text {a }}$, where $K$ is $1.33 \mathrm{ml} / \mathrm{g},[D P]$ is the average degree of polymerisation and $a$ is 0.905 .

The characterization of the washed samples was performed by means of Fourier transform infrared spectroscopy in the reflection mode (ATR-FTIR) with an Alpha spectrometer FT-IR (Bruker).

The spectra were acquired in the $4000-400 \mathrm{~cm}^{-1}$ range at the $4 \mathrm{~cm}^{-1}$ spectral resolution. A total of 120 scans were recorded and the resulting inteferogram was averaged.

UV/Vis diffuse reflectance spectra were performed using a Perkin Elmer Lamda 35 spectrophotometer equipped with a calibrated Spectralon integrated sphere accessory (LabSphere) and an internal sample holder (LabSphere). For the measurement the spectra of $3 \times 3 \mathrm{~cm}$ paper samples were recorded in the range $200-1100 \mathrm{~nm}$, the measurement speed was $120 \mathrm{~nm} / \mathrm{min}$, the interval $1 \mathrm{~nm}$ and the cycle time $1 \mathrm{~s}$. Paper samples were analysed using the UV/Vis spectroscopy method to evaluate the absorption intensity and colour of the samples of surfactant solutions before and after the thermal aging of these samples.

The surface morphology of the paper samples (analysis SEM/EDX) was investigated using a Hitachi TM3000.

The thermogravimetric (TG) and differential thermogravimetric (DTG) analysis was carried out for the paper samples non-washed, washed only in water and with surfactants: $1 \%$ Amytis, $1 \%$ Tinuvet JUN HC, $1 \%$ Tween 20, 1\% Triton X-100, 1 and 2\% P3-Triquart, 0.7 and 1\% Bromosept 50 aqueous solutions. The analysis used STA6000 Pyri 1 (Perkin-Elmer, USA), a thermal analyzer. The analysis was done under nitrogen in the temperature range from 30 to $900^{\circ} \mathrm{C}$, with the $10^{\circ} \mathrm{C} / \mathrm{min}$ heating rate.

\section{RESULTS AND DISCUSSION}

The paper samples were washed in water or in water with surfactants and then aged at $85^{\circ} \mathrm{C}$ for $500 \mathrm{~h}$. The acidity measurements $(\mathrm{pH})$ of the paper samples before and after aging were obtained. The $\mathrm{pH}$ values of the paper samples washed with a surfactant solution and aged (100, 300 and $500 \mathrm{~h}$ ) are presented in Table 1. The $\mathrm{pH}$ values of cold extraction of all the samples decreased after the thermal aging. Those samples that were washed with $1 \%$ Bromosept 50 and $1 \%$ and $2 \%$ of $\mathrm{P} 3$-Triquart solutions had the highest $\mathrm{pH}$ values, respectively, 7.07, 7.07 and 7.25.

After aging for $500 \mathrm{~h}$ at $85^{\circ} \mathrm{C}$ the $\mathrm{pH}$ biggest change is obtained in the extracts of non-washed paper $(\Delta \mathrm{pH} 0.71)$ and paper washed with the $2 \% \mathrm{P} 3$-Triquart aqueous solution $(\Delta \mathrm{pH} 0.62)$. The smallest $\mathrm{pH}$ value change was in the samples, which were washed with the 0.7 and $1.0 \%$ aqueous solutions of Bromosept $50(\Delta \mathrm{pH}$ about 0.35$)$. It can be seen (Table 1) that the $\mathrm{pH}$ of the samples, that were washed in water with surfactant solutions and thermally aged for $500 \mathrm{~h}$, remained close (pH higher than 6.0) to that of the paper samples treated only with distilled water.

The viscometric determination of DP was performed according to the standard ISO 5351/04 procedure, using fresh cupriethylenediamine as a solvent. Observing the degree of polymerization of the samples before and after aging, it is convenient to compare cleaved glycosidic bands, expressed in percentages. This value is proportional to the size $1 / \mathrm{DP}_{\mathrm{t}}$ $1 / \mathrm{DP}_{\mathrm{o}}$, where $\mathrm{DP}_{0}$ and $\mathrm{DP}_{\mathrm{t}}$ are the degree of polymerization at the initial time (unaged samples) and after the time $t$ (after $500 \mathrm{~h}$ aging at $85^{\circ} \mathrm{C}$ ). The degree of polymerization before and after the sample aging and the percentage of cleaved glycoside bonds were calculated (Table 2).

The highest degree of polymerization was obtained for non-washed paper (1153). The lowest DP before and after aging was calculated for the samples washed with Bromosept 50 and P3-Triquart solutions as compared to others, but the percentage of cleaved glycosidic bonds is only $0.001 \%$, which means over half less than that of the filter paper $-0.0021 \%$. The samples washed with $1 \%$ Amytis have a similar degree

Table 1. $\mathrm{pH}$ values of the paper samples before and after aging at $85^{\circ} \mathrm{C}$ for $500 \mathrm{~h}$

\begin{tabular}{|c|c|c|c|c|}
\hline \multirow{2}{*}{$\begin{array}{c}\text { Sample } \\
\text { paper washed in water with a surfactant }\end{array}$} & \multirow{2}{*}{ pH before aging } & \multicolumn{3}{|c|}{$\mathrm{pH}$ values after aging for $500 \mathrm{~h}$ at $85^{\circ} \mathrm{C}$} \\
\hline & & $100 \mathrm{~h}$ & $300 \mathrm{~h}$ & $500 \mathrm{~h}$ \\
\hline Paper & 6.90 & 6.74 & 6.50 & 6.19 \\
\hline Only water & 6.67 & 6.37 & 6.12 & 5.94 \\
\hline $1.0 \%$ Amytis & 6.87 & 6.63 & 6.52 & 6.40 \\
\hline 1.0\% Tween 20 & 6.87 & 6.83 & 6.59 & 6.42 \\
\hline 1.0\% Tinuvetin JUN HC & 6.67 & 6.51 & 6.31 & 6.13 \\
\hline $1.0 \%$ Triton $\mathrm{X}-100$ & 6.94 & 6.87 & 6.69 & 6.45 \\
\hline $0.7 \%$ Bromosept 50 & 6.97 & 6.85 & 6.79 & 6.62 \\
\hline $1.0 \%$ Bromosept 50 & 7.07 & 7.02 & 6.79 & 6.72 \\
\hline 1.0\% P3-Triquart & 7.07 & 6.83 & 6.62 & 6.57 \\
\hline 2.0\% P3-Triquart & 7.25 & 7.13 & 6.86 & 6.63 \\
\hline
\end{tabular}


Table 2. Degree of polymerization and cleaved glycosidic bonds of paper samples

\begin{tabular}{c|c|c|c}
\hline \multirow{2}{*}{$\begin{array}{c}\text { Sample } \\
\text { paper washed in water with a surfactant }\end{array}$} & \multicolumn{2}{|c|}{ DP (r.u.) } & Cleaved glycosidic bonds, $\%$ \\
\cline { 2 - 4 } & Non-aged & After $\mathbf{5 0 0 ~} \mathbf{~}$ & After $\mathbf{5 0 0 ~} \mathbf{~}$ \\
\hline Paper & 1153 & 1126 & 0.0021 \\
\hline Only water & 1124 & 1115 & 0.0007 \\
\hline 1\% Amytis & 1147 & 1128 & 0.0015 \\
\hline 1\% Tween 20 & 1145 & 1114 & 0.0025 \\
\hline 1\% Tinuvetin HC JUN & 1138 & 1096 & 0.0034 \\
\hline 1\% Triton x-100 & 1105 & 1086 & 0.0016 \\
\hline 0.7\% Bromosept 50 & 1060 & 1047 & 0.0011 \\
\hline $1 \%$ Bromosept 50 & 1071 & 1053 & 0.0016 \\
\hline 1\% P3-Triquart & 1086 & 1074 & 0.0010 \\
\hline 2\% P3-Triquart & 1071 & 1060 & 0.0010 \\
\hline
\end{tabular}

of polymerization as the non-washed paper, but the amount of cleaved glycoside bonds is smaller. The highest percentage of cleaved glycoside bonds is in the sample that has been washed in the $1 \%$ Tinuvetin HC JUN solution, more than $0.003 \%$, while the lowest percentage is in the water-washed sample $-0.0007 \%$. It can be easily seen that changes of the degree of polymerization and the amount of cleaved glycosidic bonds after washing with all used surfactants are very small. The decrease of the degree of polymerization straightforwardly affects all the mechanical properties.

Decrease in the degree of polymerization is related to paper hydrolysis, while increasing of the number of carbonylic groups is due to oxidation of paper. Vibrational and absorp- tion spectroscopy is often used to resolve the cellulose structure or the crystalline phase, and the hydrogen bond network. Application of in situ FTIR measurements to directly look into changes of the cellulose structure during degradation is possible. So, the functional group changing of paper was studied by infrared and UV/Vis absorbance spectroscopy.

Infrared spectroscopy was applied to investigate the state of conservation of the paper samples after washing with different surfactants and artificial aging for $500 \mathrm{~h}$ at $85^{\circ} \mathrm{C}$. Infrared spectroscopy is very sensible to the change of the structure and the functional group of the analysed cellulose molecules. The obtained IR spectrum of non-washed paper and washed paper samples is presented in Fig. 1.

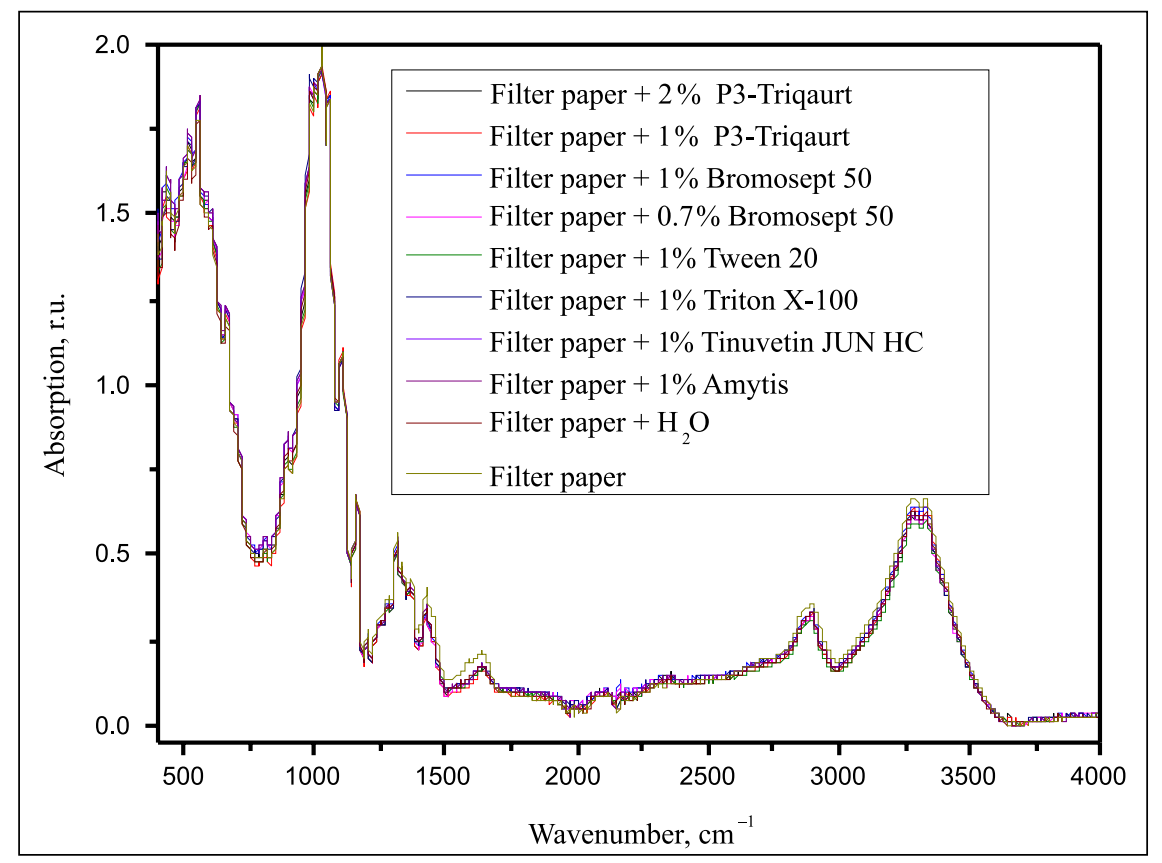

Fig. 1. The IR spectrum of the samples after washing with surfactants and aging for $500 \mathrm{~h}$ at $85^{\circ} \mathrm{C}$ 
The obtained results showed only the characteristic peaks of cellulose: absorption $3500-3300 \mathrm{~cm}^{-1}$ corresponds to - $\mathrm{OH}$ stretching, asymmetric and symmetric $\mathrm{CH}_{2}$ and $-\mathrm{CH}_{3}$ at $2900-2800 \mathrm{~cm}^{-1}, \mathrm{CH}_{2}$ symmetric bending at $1362, \mathrm{OH}$ in plane bending at $1110 \mathrm{~cm}^{-1}$ corresponding to vibration of $-\mathrm{CH}$ groups. The interval of $1730-1625 \mathrm{~cm}^{-1}$ shows a low intensity absorption peak as corresponding to keto-, diketoaldehyde and carboxy groups. The stretching peaks at 1440 and $1250 \mathrm{~cm}^{-1}$ indicate $\mathrm{C}-\mathrm{O}$ bond vibrations, and the band at $1000 \mathrm{~cm}^{-1}$ is attributed to $\mathrm{C}-\mathrm{O}$ (near $\mathrm{OH}$ ). In general, after aging, the carbonyl/carboxyl peak can be formed, and increasing of absorbance in the FTIR spectrum at the region $1600-1700 \mathrm{~cm}^{-1}$ can be observed in paper. However, the changes can be masked by the presence of free water in the paper near $1640-1700 \mathrm{~cm}^{-1}$. It can be noted that the absorption band intensities of differently washed samples differ very slightly, so the impact of used surfactants on paper functional group changes is negligible.

The UV/Vis absorbance spectra of paper and washed paper samples are presented in Figs. 目 and 3. The degradation through chemical changes of macromolecules could have two consequences: loss of physical properties and change in appearance.

The greater intensity of absorption of non-aged samples bands was observed at 230 and $282 \mathrm{~nm}$. The highest values of absorption in the UV region of the sample washed with 1 and $2 \%$ P3-Triquart solutions in respect to the sample washed only with water are due to the aromatic molecular structure of surfactants - alkyldmethylbenzylammonium compound. The absorbance of other samples is close to paper spectra.

After aging of paper and washed paper samples the overall intensity in all region increases. During the paper aging, especially oxidative degradation, the chromophores such as $\mathrm{CO}, \mathrm{C}=\mathrm{C}$ or $\mathrm{C}=\mathrm{N}$ bonds are formed, they can be observed in the $\mathrm{VU} / \mathrm{Vis}$ region and they affect the growth of the wavelength portion of the visible spectrum $(\lambda<430 \mathrm{~nm})$. A yellowish shade can occur due to the appearance of condensed molecules or interaction functional groups of surfactant molecules. As an example, the amino group of ammonium compounds could interact with the aldehyde groups of paper that arise during aging, and the result is yellow imine compounds. The above-mentioned features are more intense in the sample washed with the surfactants Bromosept 50 or P3-Triquart with respect to Amytis and Tinovetin Jun HC. Moreover, the P3-Triquart samples show higher absorbance in the blue region, thus confirming a shift to the yellow colour of paper.

Scanning electron microscopy was used for the study of the paper fiber structure. The analysis was done for the samples washed with surfactants and compared with the aged samples (Fig. 4, before and after aging for $500 \mathrm{~h}$ at $85^{\circ} \mathrm{C}$ ).

The paper samples after washing procedures and thermal aging are a little swollen, but there are no visible fiber tears or other damage. Thus, during the wash fiber swelling and irreversible changes in the dimensions of paper media cannot be avoidable. The major destruction in the samples washed with surfactants was not observed even after $500 \mathrm{~h}$ of aging.

The thermogravimetric (TG) analysis allows monitoring the degree of paper destruction. The TG curves can be made of paper deterioration due to chemical (hydrolysis and oxidation) and physical factors of the paper in the input components. The analysis was performed for the samples that were affected by $1 \%$ Amytis, $1 \%$ Tinuvetin JUN HC,

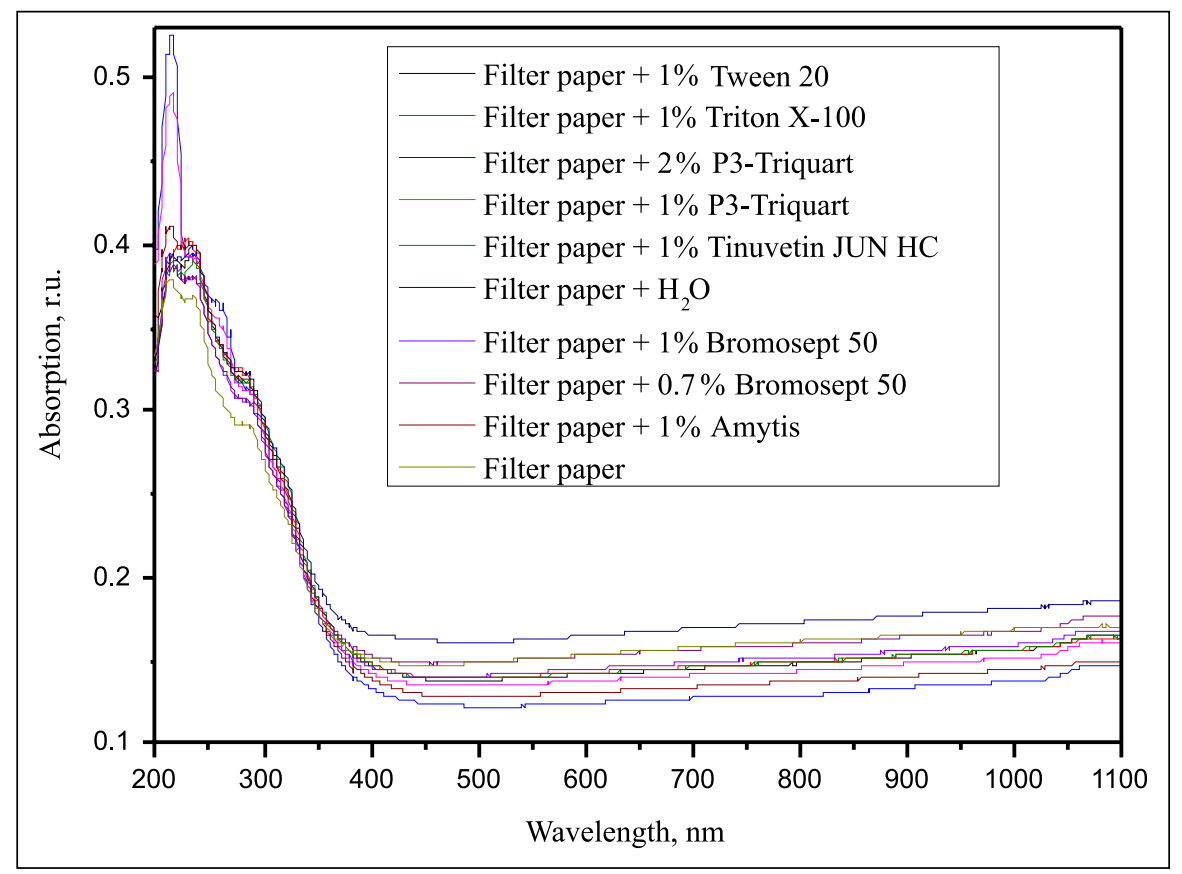

Fig. 2. The VU/Vis absorption spectra of paper and washed samples before aging 


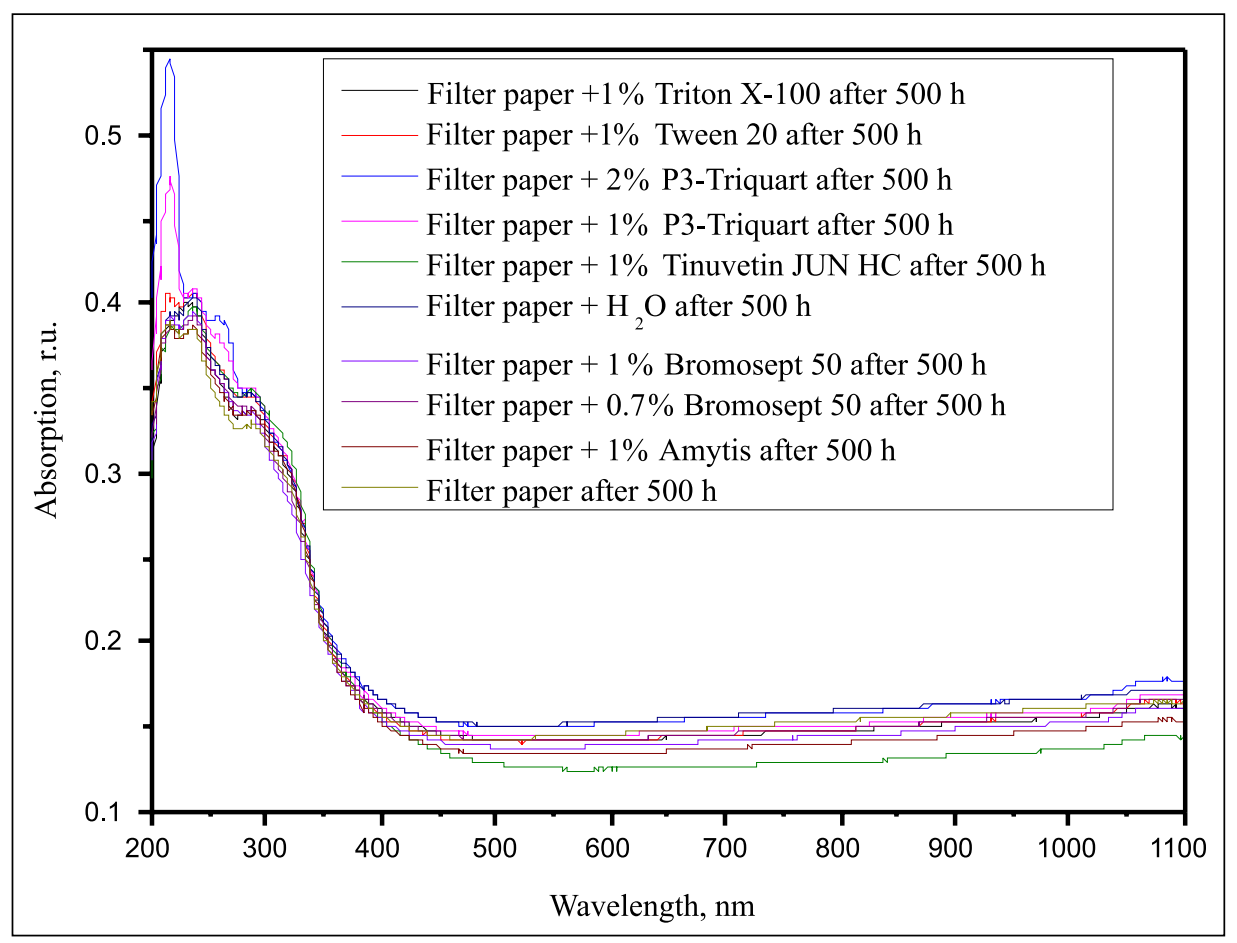

Fig. 3. The VU/Vis absorption spectra of paper and washed samples after aging for $500 \mathrm{~h}$ at $85^{\circ} \mathrm{C}$

1\% Tween 20, 1\% Triton X-100, 1 and 2\% P3-Triquart, 0.7 and $1 \%$ Bromosept 50 . The results were compared with the standard (unwashed and treated with distilled water samples) before and after heat aging. The thermogravimetric analysis was performed under nitrogen at $30-900^{\circ} \mathrm{C}$, and the results are given in Fig. 5 and Table 3.

Both materials (Bromosept 50 and P3-Triquart) have positive characteristics, such as high pH (7.07 and 7.25) and low percentage broken glycoside bonds values (0.001\%). However, Bromosept 50 was rejected on the ground that it treated the samples characterized by the lowest thermal resistance (decomposition temperature before aging is $347.20^{\circ} \mathrm{C}$, after heat aging it is $340.96^{\circ} \mathrm{C}$ ) and the lowest degree of polymerization (before and after aging, 1060.2 and 1047.7).
Neither one of the sample temperature change is greater than $10^{\circ} \mathrm{C}$, and the samples are compared to benchmarks. The decomposition temperatūres of unaged samples washed with the $1 \%$ Amytis $\left(352.57^{\circ} \mathrm{C}\right)$ and $1 \%$ Tinuvetin HC JUN $\left(350.14^{\circ} \mathrm{C}\right)$ solutions are similar to those of non-washed $\left(352.73^{\circ} \mathrm{C}\right)$ and washed with distilled water $\left(350.14^{\circ} \mathrm{C}\right)$ samples. The standard decomposition temperature of the samples before and after aging differs by $\sim 5^{\circ} \mathrm{C}$. However, after the ageing the decomposition temperatures of the paper samples washed with the $0.7 \%$ or $1 \%$ Bromosept 50 solution and aged are much lower $\left(347.20^{\circ} \mathrm{C}\right.$ and $340.96^{\circ} \mathrm{C}$, respectively), it is confirmed by the higher paper degradation process degree. It can be assumed that it was influenced by the minimum destruction of cellulose molecules initiated by Bromosept 50 .

Table 3. Paper sample weight loss and degradation temperature values before and after aging

\begin{tabular}{|c|c|c|c|c|}
\hline \multirow{2}{*}{ Paper sample washed in water with } & \multicolumn{2}{|c|}{ Weight loss, \% } & \multicolumn{2}{|c|}{ Initial temperature at which the material begins to decay, ${ }^{\circ} \mathrm{C}$} \\
\hline & Unaged & After $500 \mathrm{~h}$ & Unaged & After $500 \mathrm{~h}$ \\
\hline Non-washed paper & 97.62 & 98.28 & 352.73 & 346.89 \\
\hline Only water & 97.97 & 98.00 & 350.13 & 343.71 \\
\hline 1\% Tinuvetin HC JUN & 97.23 & 97.76 & 350.14 & 347.26 \\
\hline 1\% Tween & 96.13 & 97.46 & 354.41 & 351.25 \\
\hline $1 \%$ Triton $x-100$ & 97.32 & 97.64 & 348.90 & 348.72 \\
\hline $1 \%$ Amytis & 97.81 & 97.72 & 352.57 & 348.57 \\
\hline 0.7\% Bromosept 50 & 96.80 & 97.63 & 347.20 & 344.82 \\
\hline 1\% Bromosept 50 & 96.51 & 97.93 & 349.97 & 340.96 \\
\hline 1\% P3-Triquart & 97.16 & 97.68 & 349.96 & 346.19 \\
\hline 2\% P3-Triquart & 95.71 & 97.67 & 348.02 & 341.88 \\
\hline
\end{tabular}



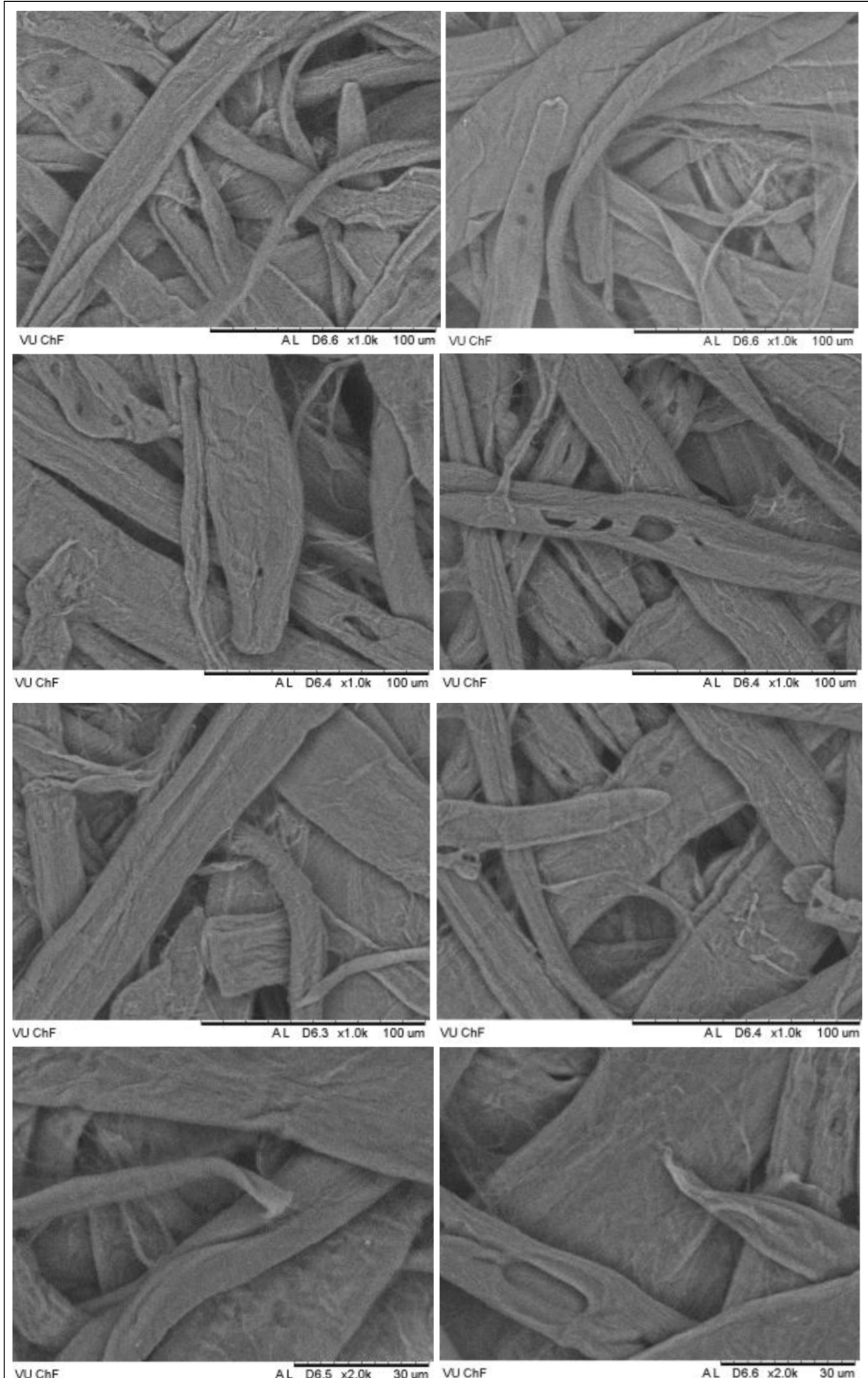

Fig. 4. SEM images of the aged samples for $500 \mathrm{~h}$ at $85^{\circ} \mathrm{C}$. Samples: (a) non-washed paper; (b) paper washed only in water, washed in water with (c) 1\% Amytis, (d) 1\% Tinuvet JUN HC, (e) 1\% Tween 20, (f) 1\% Triton X-100, (g) 1\% Bromosept 50, (h) 1\% P3-Triquart 


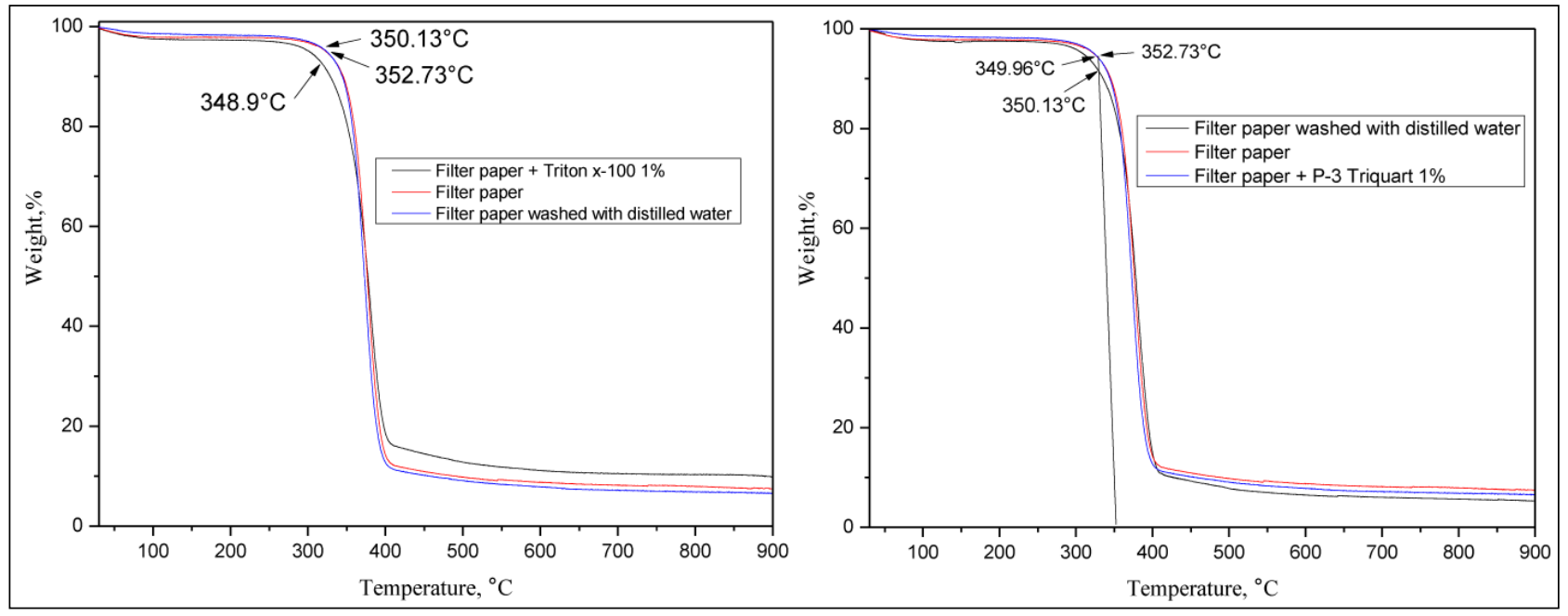

Fig. 5. TG curves of the samples: (a) treated with 1\% Triton X-100 solution; (b) treated with 1\% P3-Triquart solution

The studies showed that Amytis has a number of positive qualities, but because of its uncertain chemical structure and instability, after years materials and solutions tend to thicken and form dispersions, and it was decided to refuse this matter in further studies. After thermal aging, the $\mathrm{pH}$ of the samples treated with Tinuvetin JUN HC is greatest (6.13), the percentage loss of glycosidic bonds is highest $(0.0034 \%)$, the Tween 20 and Amytis aqueous solutions are not stable and after a while they become cloudy and change their colour.

\section{CONCLUSIONS}

The surfactants impurities affect the paper aging process, and it was discovered that all of the tested surface-active materials of washing procedures had no significant impact on the acidity of paper. The biggest change in the $\mathrm{pH}$ of the samples after heat aging $(500 \mathrm{~h})$ was detected in the samples that had not been washed or treated with PAM solutions. The most glycosylated bonds change the $1 \%$ Tinuvetin Jun solution and the standard to a minimum, however this change is minimal. Therefore, it can be said that the influence of the degree of polymerization is very small and minimally changing the paper degree of polymerization. It was found that washing PAM solutions had a negligible influence on the thermal stability of paper, except Bromosept 50 solution. The SEM analysis allowed us to see that during washing it was impossible to avoid fiber swelling and irreversible changes in the dimensions of paper media, but no signs of destruction were observed even after $500 \mathrm{~h}$ lasting thermal aging. After thermal aging, there is no significant change in the absorption bands in the UV/Vis spectra except for the sample treated with P3-Triquart solutions. Although the apparent change in colour is not monitored in the evaluation of the results of the research, it is necessary to select the washing procedures, their duration and the course of action very carefully and accurately. It is also recommended to wash the paper with distilled water after washing with PAM solutions.

Received 16 April 2018

Accepted 9 June 2018

\section{References}

1. M. C. Area, H. Cheradame, BioResources, 6(4), 5307 (2011).

2. A. M. Conte, O. Pulci, A. Knapik, J. Bagniuk, R. Del Sole, J. Lojewska, M. Missori, Phys. Rev. Lett., 108(15), 158 (2012).

3. L. Lagurdia, E. Vassallo, E. Cappitelli, E. Mesto, A. Cremona, C. Sorlini, G. Bonizzoni, Appl. Surf. Sci., 252(4), 1159 (2005).

4. V. S. Šelih, M. Strlič, J. Kolar, B. Pihlar, Pol. Deg. Stab., 92(8), 1476 (2007).

5. J. Pérez, J. Munoz-Dorado, T. de la Rubia, J. Martínez, Int. Microbiol., 5(2), 53 (2002).

6. D. L. Crawford, R. L. Crawford, Appl. Environ. Microbiol., 31(5), 714 (1976).

7. A. Timar-Balazsy, Stud. Conserv., 45(Suppl. 3), 46 (2000).

8. S. Zervos, I. Alexopoulou, Cellulose, 22(5), 2859 (2015).

9. C. Isca, L. Fuster-López, D. J. Yusá-Marco, A. Casoli, Cellulose, 22(5), 3047 (2015).

10. V. Daniels, J. Kosek, Restaurator, 25(2), 81 (2004).

11. V. Daniels, J. Kosek, Restaurator, 25(4), 260 (2004).

12. C. Stavroudis, T. Doherty, R. Wolbers, WAAC Newsletter, 27(2), 17 (2005).

13. Z. Barov, Stud. Conserv., 35(Suppl.), 19 (1990).

14. A. Burnstock, R. White, Stud. Conserv., 35(Suppl.), 111 (1990).

15. J. A. Fields, A. Wingham, F. Hartog, V. Daniels, J. Am. Inst. Conservat., 43(1), 55 (2004).

16. M. Baglioni, R. Giorgi, D. Berti, P. Baglioni, Nanoscale, 4(1), 42 (2012).

17. D. Myers, Surfactant Science and Technology, 3rd. edn., p. 375, Hoboken, New Jersey (2006). 
18. J. Karbowska-Berent, T. Kozielec, J. Jarmiłko, B. Brycki, Restaurator, 32(3), 223 (2011).

19. S. Sequeira, E. J. Cabrita, M. F. Macedo, Intern. Biodet. Biodeg., 74, 67 (2012).

20. M. Nittérus, Restaurator, 21(1), 25 (2000).

21. K. Rajkowska, A. Koziróg, A. Otlewska, M. Piotrowska, P. Nowicka-Krawczyk, B. Brycki, B. Gutarowska, Acta Bioch. Pol., 63(1), 153 (2016).

22. A. Lipińska-Ojrzanowska, J. Walusiak-Skorupa, Med. Pr., 65(5), 675 (2014).

23. ISO 6588-1: 2005, Paper, board and pulps - Determination of $\mathrm{pH}$ of aqueous extracts - Part 1: Cold extraction.

24. J. Karbowska-Berent, T. Kozielec, J. Jarmiłko, B. Brycki, Restaurator, 32, 223 (2011).

25. E. Obłąk, A. Gamian, Postepy Hig. Med. Dosw. 64, 201 (2010).

26. ISO 5351: 2004(E), Paper and board - Determination of limiting viscosity number in cupri-ethylendiamine (CED) solution.
Milda Liubinienė, Justė Kupčiūnaitė, Aldona Beganskienė

\section{PAVIRŠINIO AKTYVUMO MEDŽIAGU ITTAKOS POPIERIAUS SAVYBĖMS IR SENĖJIMO PROCESUI TYRIMAS}

Santrauka

Paviršinio aktyvumo medžiagos (PAM) mažina vandens paviršiaus įtempti, pagerina vilgymą, veiksmingiau išplauna nešvarumus ir paspartina plovimo procesą. PAM medžiagos turi teigiamų savybių ir yra plačiai naudojamos tekstilès ir odos valymo procesuose. Norint šias medžiagas pritaikyti popieriaus plovimo procesuose, reikia parinkti tikslius šių medžiagų kiekius, taip pat rekomenduojama atlikti daugiau perplovimų, kad būtų pašalinti minètų medžiagų likučiai. Popieriaus bandiniai buvo veikiami nedidelių (1 ir $2 \%$ ) koncentracijų vandeniniais tirpalais. Sausi ir išpresuoti bandiniai buvo termiškai sendinami ir tiriami ATR-FTIR, UV/Vis, SEM bei termogravimetrinès analizès metodais, taip pat siekiama nustatyti PAM įtaką celiuliozès polimerizacijos laipsnio bei rūgštingumo kitimui popieriui senstant. Ivertinus visų tyrimų rezultatus nustatyta, kad paviršinio aktyvumo medžiagų naudojimas popieriaus plovimo procedūrose jas pagreitina, palengvina nešvarumų ir tirpiųjų rūgščių pašalinimą. 
